

\title{
REGULARITIES IN PROPAGATION OF OPENED CORROSION-INDUCED CRACKS IN CONCRETE
}

\author{
Vidmantas Jokūbaitis \\ Dept of Reinforced Concrete and Masonry Structures, Vilnius Gediminas Technical University, \\ Saul tekio al.11,LT-10223 Vilnius, Lithuania.E-mail: gelz@st.vtu.lt \\ Received 5 June 2006; accepted 5 Jan 2007
}

\begin{abstract}
Long and short-term (accelerated with simulation of pressure developed by compressed rust) experimental investigations were accomplished. It was investigated in long-term tests the relationship between the width of the longitudinal cracks on the concrete surface and close to the reinforcement, and relation between these widths and corrosioninduced damages in the reinforcement; parameters of these relationships were established. In short-time investigations it was tried to clarify the influence of transverse reinforcement and opened normal cracks on the nature of longitudinal cracks propagation. It has been determined that the character and the rate of propagation of the longitudinal cracks depend on distribution of transverse reinforcement and normal cracks along a member.
\end{abstract}

Keywords: corrosion, the layer of rust, cracks, transverse reinforcement.

\section{Introduction}

In structures exposed to an aggressive environment corrosion usually starts in reinforcement embedded in concrete. A growing layer of rust around the reinforcement bars induces tension stresses in the concrete and they cause cracking. Investigations of reinforced concrete structures in Lithuania show that the major part of these structures (excluding reinforced concrete structures situated in heated premises) are with open longitudinal cracks due to corrosion of reinforcement just after 10-20 years in use. Similar problems exist in construction practice of other countries as well. Therefore nowadays the regularity of propagating longitudinal cracks opened due to reinforcement corrosion in concrete beams has become an object of wide investigations. As a rule, in such investigations methods of accelerated reinforcement corrosion process are employed with simulation of pressure developed by rust [1] or with an increasing aggressiveness of environment $[2,3]$. Interesting data are presented in [2] about the effect of thickness and density of concrete cover to reinforcement at the time of initiation of longitudinal cracks. In experimental investigations in reinforced concrete beam [3] a relationship between the width of a longitudinal crack and percentage of loss in the mass of reinforcing steel due to its corrosion, an analytical expression and multi-parametric stochastic model for the longitudinal crack width are proposed [4].

There are few investigations in to the propagation of longitudinal cracks in the reinforced concrete based on fracture mechanics criteria [5, 6]. Efforts to implement into a practical use possibilities of the models for cracks propagation according to these criteria is restricted by the lack of data on investigations in the relationship between parameters of longitudinal cracks and the rate of reinfor- cement corrosion, about relationship between the propagation character of these cracks and position of the longitudinal and transverse reinforcement in the crosssection of the member and the spacing of the normal cracks, about the influence of the concrete structure and the character of the load resulting in longitudinal cracks.

In this article data on experimental investigations in the width of these cracks on the surface of concrete and reinforcing bars, in relations between corrosive damage to the reinforcement (decrease in cross-sectional area) and these widths, as well as in influence of transverse reinforcement and spacing of normal cracks on propagation of longitudinal cracks are analysed.

\section{Concrete cracking due to corrosion of reinforcing steel}

Relationship between the width of the longitudinal crack $w_{k}$ at the concrete surface and reduction in diameter of reinforcing bar $\Delta d$ due to steel corrosion is expressed by [5]:

$$
\Delta d(\Psi-1)=0,5\left(\lambda_{1}+\lambda_{2}\right) w_{k},
$$

where $\Psi=\delta_{\mathrm{r}} / \Delta d$, and $\delta_{\mathrm{r}}-$ total thickness of the layer of compressed rust in the plane of the bar diameter, coefficients $\lambda_{1}=w_{k 1} / w_{k}$ and $\lambda_{2}=w_{k 2} / w_{k}$ (Fig 1), $w_{k 1}$ and $w_{k 2}-$ widths of the cracks at one and at the opposite sides of reinforcement bar, very close to its surface. Considering that the widths of longitudinal cracks remain proportional to the distances to the crack tip, the coefficient

$$
\lambda_{1}=d\left(1-\lambda_{2}\right) /(d+\delta)+\lambda_{2} .
$$

By expression (2) a graph illustrating variation of the sum of $\lambda_{1}$ and $\lambda_{2}$ values in relation to the ratio $\delta / d$ was produced (Fig 2). Values of this variable ratio (1,0 to 2,5$)$ correspond to provisions of [7] for design of reinforced 
concrete structures when the reinforcement bar diameter is 16 to $28 \mathrm{~mm}$. Values of these coefficients can vary within limits $0,3 \leq \lambda_{1} \leq 1$ and $0 \leq \lambda_{2} \leq 1$. Validation of conditions (1) and (2) can be proved by long-time experimental investigations.
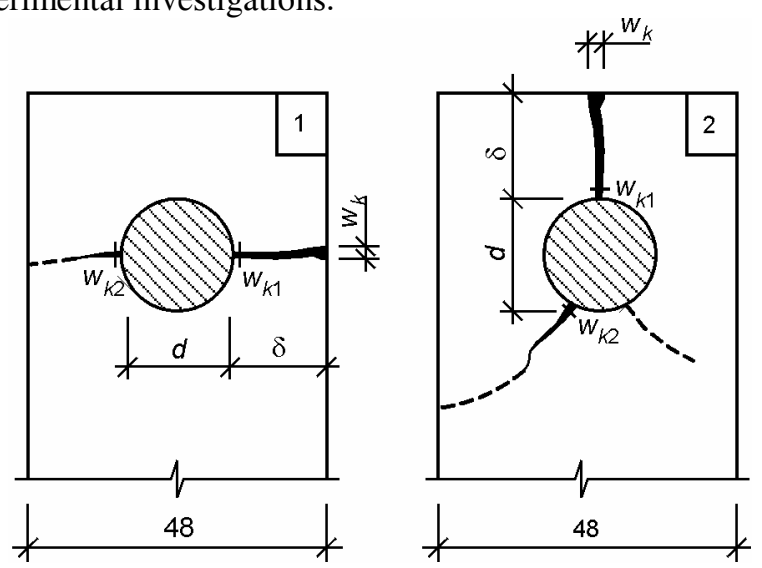

Fig 1. Steel corrosion-induced cases of cracking in the concrete (segments of cracks opened later by broken lines)



Fig 2. Relationship between the sum of coefficients $\lambda_{1}$ and $\lambda_{2}$ and ratio $\delta / d$

16 specimens from fine aggregate concrete (1 part of Portland cement and 5 parts of sand with the particles of the size up to $2,5 \mathrm{~mm}$, water/cement ratio $W / C=0,5$ and $0,7)$ were manufactured. In the specimens the size of which $100 \times 100 \times 48 \mathrm{~mm}$ smooth steel bars in diameter of $18 \mathrm{~mm}( \pm 0,1 \mathrm{~mm})\left(\sigma_{y}=283,4 \mathrm{MPa}, \sigma_{t}=422,6 \mathrm{MPa}\right)$ were cast providing a concrete cover to them with thickness of $\delta=12,3-16,1 \mathrm{~mm}$. The mean value of the ratio $\delta / d$ equals 0,8 . After 76 days of hardening the specimens were immersed up to the half of their depth into $25 \%$ solution of $\mathrm{NaCl}$. A part of the specimens with steel bars was above the solution.

After $t=2300$ days in a part of specimens the widths of the cracks $w_{k, t}, w_{k 1, t}$ and $w_{k 2, t}$ (Table 1) were recorded by means of 10 times magnifying microscope and with a specially graded strip via a magnifying glass.

Places where the cracks were widths measured are shown in Fig 1. When recording the crack widths was completed, the specimens were stored taken out of the solution. When opened cracks propagated almost up to the specimens surface (broken lines in Fig 1) after 25402590 days crack widths $w_{k, \lim }, w_{k 1, \text { lim }}$ and $w_{k 2 \text {,lim }}$ were measured (Table 1). Then the specimens were destroyed, the thickness of formed rust layer around the steel bar and reduced due to corrosion diameter and mass of this bar were recorded.

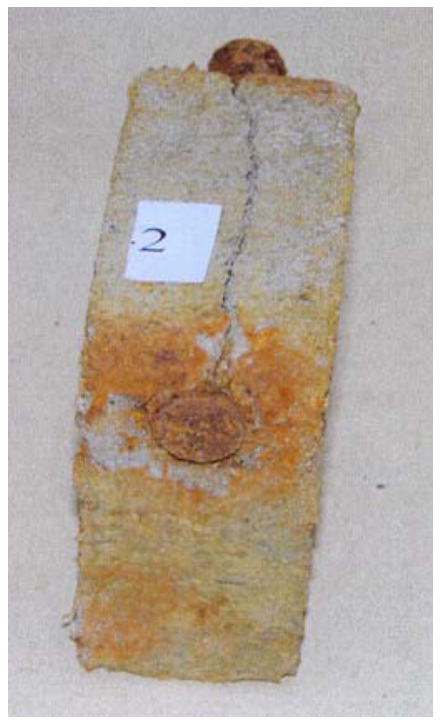

Fig 3. General view of cracking in a specimen

Tension stresses in the concrete were induced due to a formed layer of compressed rust around the steel bar and after some time cracked and the concrete cover to reinforcement spalled off the bar in two characteristic ways (Fig 1). In the second case, the crack propagated behind the bar deep inside the specimen due to the effect of the transverse shear force had several branches. For determining the $\lambda_{2}$ value only the width $\mathrm{w}_{\mathrm{k} 2}$ of the main crack branches was measured according to which spalling the concrete cover to reinforcement took place. The cover of $\delta$ in thickness in all the specimens was cut by a normal crack (Fig 3). A similar cracking in specimens has been obtained in [2] as well.

Taking value $\lambda_{2}=\lambda_{2, \text { lim }}$ of the coefficient $\lambda_{\text {lcal }}$ obtained by calculation according to formula (2) in average only by $3 \%$ differ from values of $\lambda_{1, \lim }$ (Table 1 ). Thus the investigation results indicate that in the plane of crack proportional relationship between the cracks width and their distances from the tip of the crack is valid, ie it is possible to ignore an influence of transverse shear force in determining coefficients $\lambda_{1}$ and $\lambda_{2}$. It is possible to assume that the crack of normal fracture was opened in the concrete.

The layer of rust formed uniformly around the whole perimeter of the bar except for specimens Nos 8 and 16 in which the layer of rust formed just on the one side.

Due to a chloride aggression in steel bars of some specimens several corrosion pittings appeared. Diameters of the bars ends projecting from the concrete corroded by $60 \%$ more than those in concrete. When the ratio $W / C=0,7$, the average reduction of diameters of steel 
Table 1. Parameters of cracking in the concrete and reduction in bar diameter due to steel corrosion

\begin{tabular}{|c|c|c|c|c|c|c|c|c|c|c|c|c|c|c|c|}
\hline \multirow{2}{*}{$\begin{array}{c}\text { Specimen } \\
\text { No }\end{array}$} & \multirow{2}{*}{$W / C$} & \multicolumn{2}{|c|}{$w_{k}, \mathrm{~mm}$} & \multicolumn{2}{|c|}{$w_{k 1}, \mathrm{~mm}$} & \multicolumn{2}{|c|}{$w_{k 2}, \mathrm{~mm}$} & \multicolumn{2}{|c|}{$\lambda_{1}$} & \multicolumn{2}{|c|}{$\lambda_{2}$} & \multirow{2}{*}{$\begin{array}{c}\Delta d_{o b s,}, \\
\mathrm{~mm}\end{array}$} & \multirow{2}{*}{$\Psi$} & \multirow{2}{*}{$\begin{array}{l}\Delta d, \\
\mathrm{~mm}\end{array}$} & \multirow{2}{*}{$\lambda_{\text {lcal }}$} \\
\hline & & $w_{k, t}$ & $w_{k, \lim }$ & $w_{k 1, t}$ & $w_{k 1, \lim }$ & $w_{k 2, t}$ & $w_{k 2, \lim }$ & $\lambda_{1, \mathrm{t}}$ & $\lambda_{1, \lim }$ & $\lambda_{2, \mathrm{t}}$ & $\lambda_{2, \lim }$ & & & & \\
\hline 1 & \multirow{8}{*}{0,5} & 0,65 & 1,00 & 0,35 & $*$ & $*$ & 0,35 & 0,54 & - & - & 0,35 & 0,43 & 2,79 & - & 0,74 \\
\hline 2 & & 0,45 & 1,00 & 0,20 & 0,50 & 0,10 & 0,20 & 0,44 & 0,50 & 0,22 & 0,20 & 0,43 & 2,33 & 0,26 & 0,64 \\
\hline 3 & & 0,60 & 0,90 & $*$ & 0,70 & * & 0,25 & - & 0,78 & - & 0,28 & 0,38 & 3,16 & 0,22 & 0,70 \\
\hline 4 & & 0,40 & 1,00 & $*$ & 0,50 & 0,10 & 0,25 & - & 0,50 & 0,25 & 0,25 & 0,43 & 2,79 & 0,21 & 0,66 \\
\hline 5 & & $*$ & 1,00 & $*$ & $*$ & $*$ & * & - & - & - & - & 0,33 & 3,64 & - & - \\
\hline 6 & & $*$ & 0,50 & $*$ & 0,50 & $*$ & 0,25 & - & 1,00 & - & 0,50 & 0,43 & 2,32 & 0,28 & 0,77 \\
\hline 7 & & $*$ & 2,00 & $*$ & 1,40 & $*$ & 0,15 & - & 0,70 & - & $\begin{array}{l}0,08 \\
\end{array}$ & 0,43 & 2,79 & 0,44 & 0,58 \\
\hline 8 & & $*$ & 0,90 & $*$ & 0,60 & * & 0,20 & - & 0,67 & - & 0,22 & 0,30 & 2,00 & 0,40 & 0,66 \\
\hline 9 & \multirow{9}{*}{0,7} & 1,00 & 2,00 & 0,90 & 1,00 & 0,30 & 0,30 & 0,90 & 0,50 & 0,30 & 0,15 & 0,53 & 1,89 & 0,73 & 0,62 \\
\hline 10 & & 0,50 & 1,10 & 0,25 & 0,40 & 0,15 & 0,20 & 0,50 & 0,36 & 0,30 & 0,18 & 0,33 & 3,03 & 0,15 & 0,63 \\
\hline 11 & & 0,50 & 1,00 & $*$ & 1,00 & 0,25 & 0,40 & - & 1,00 & 0,50 & 0,40 & 0,43 & 2,79 & 0,39 & 0,72 \\
\hline 12 & & 0,50 & 1,60 & $*$ & 1,20 & 0 & 0,20 & - & 0,75 & 0 & 0,13 & 0,43 & 2,79 & 0,39 & 0,61 \\
\hline 13 & & 0,90 & 1,00 & 0,90 & 1,00 & 0,12 & 0,15 & 1,00 & 1,00 & 0,13 & 0,5 & 0,53 & 1,70 & 0,82 & 0,62 \\
\hline 14 & & $*$ & 1,50 & $*$ & $*$ & $*$ & 0,40 & - & - & - & 0,27 & 0,48 & 2,08 & - & 0,70 \\
\hline 15 & & $*$ & 1,60 & $*$ & 0,90 & $*$ & 0,35 & - & 0,56 & - & 0,22 & 0,48 & 2,08 & 0,58 & 0,64 \\
\hline 16 & & $*$ & 0,90 & $*$ & 0,50 & * & 0,12 & - & 0,56 & - & 0,13 & 0,23 & 2,61 & 0,19 & 0,60 \\
\hline \multicolumn{7}{|c|}{ Mean } & & & 0,68 & & 0,23 & 0,41 & 2,55 & 0,39 & 0,66 \\
\hline
\end{tabular}

* - widths of the cracks not measured.

bars is by about $9 \%$ greater (Table 1 ). The average reduction $\Delta d$ in bar diameter calculated according to the formula (1) is only by $5 \%$ less in comparison with directly recorded $\Delta d_{o b s}$ value and the mass calculated according to the reduced diameter is by $4,2 \%$ less. The average bars mass weighed after the test is by $4,5 \%$ less. Thus despite a wide variation of the values $\lambda_{1}, \lambda_{2}, \Psi, w_{k}$ which was effected and by errors in measurements, our experimental investigations have proved that relationships (1) and (2) may be used for analysis of propagation of longitudinal cracks in reinforced concrete and for reinforcement state assessment.

\section{Influence of normal cracks and transverse reinforcement on propagation of longitudinal cracks}

For determining the influence of spacing of normal cracks and transverse reinforcement on the width of longitudinal cracks 9 specimens of 3 series BI, BII and BIII by the 3 different thicknesses $t$ of which spacing of normal cracks was simulated and transverse reinforcement varied (Fig 4).

In each specimen 2 holes were bored, the diameter of which was conditionally considered diameter of the longitudinal reinforcement. In addition, 4 plain concrete specimens (without transverse reinforcement) of the same dimensions and the same $\sim 50 \mathrm{~mm}$ thickness of B series have been produced in which the distance $\delta$ of bored diameter of $16 \mathrm{~mm}$ holes was 24-72 mm. Aggregate for the concrete of the specimens was $d_{\max }=10 \mathrm{~mm}$, compression strength - 33,8 $\mathrm{MPa}$, tension strength $1,92 \mathrm{MPa}$, Poisson's ratio - 0,2. S500 class ribbed wire was used for transverse reinforcement.

Pressure during a short time test of the rust in the holes formed in the specimens was simulated by a method [8]. According to it, steel balls of diameter 3$5 \mathrm{~mm}$ in the hole via a steel bar in diameter (the same as a
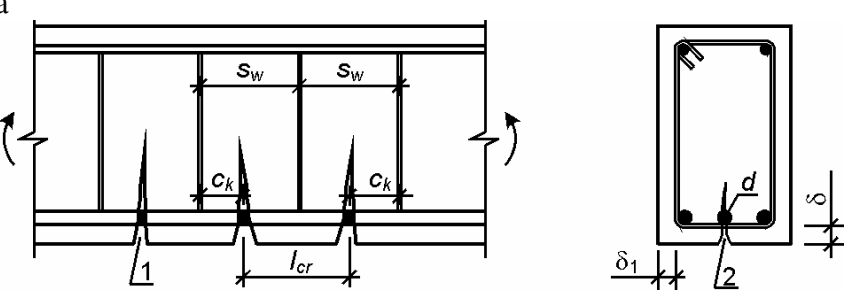

b
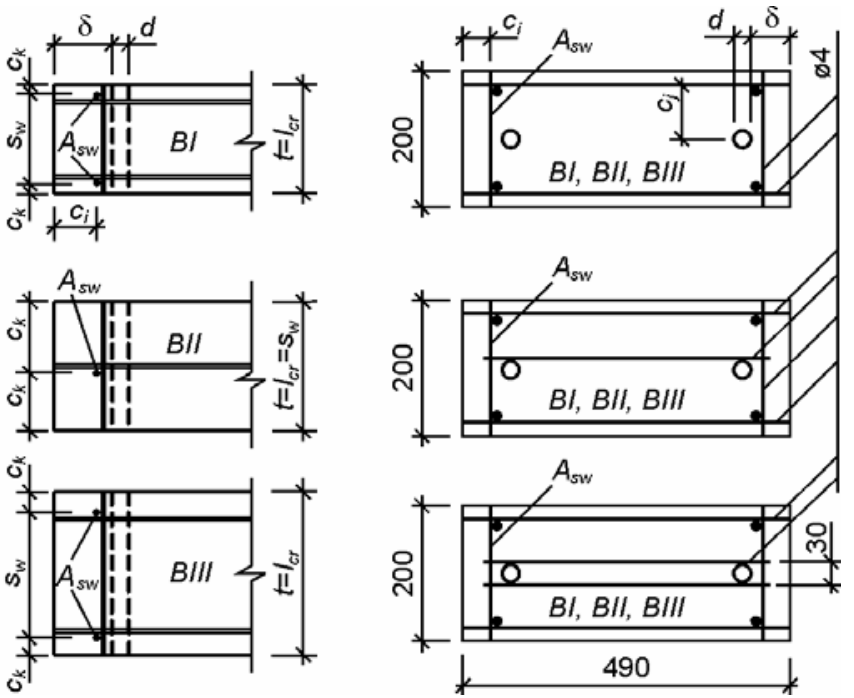

Fig 4. Cracking in reinforced concrete member (a) and dimensions and reinforcement of the specimens (b): 1 - normal crack, 2 - longitudinal crack

the hole) were pressed by a hydraulic jack with increasing steps of $0,5 \mathrm{kN}$. The step load was increased with the rate of $0,02 \mathrm{kN} / \mathrm{s}$. The length of the step was $5 \mathrm{~min}$. The width and propagation rate of the longitudinal cracks were determined by means of dial gauges of $100 \mathrm{~mm}$ and $50 \mathrm{~mm}$ gauge lengths and with $0,001 \mathrm{~mm}$ division value (Fig 5). 


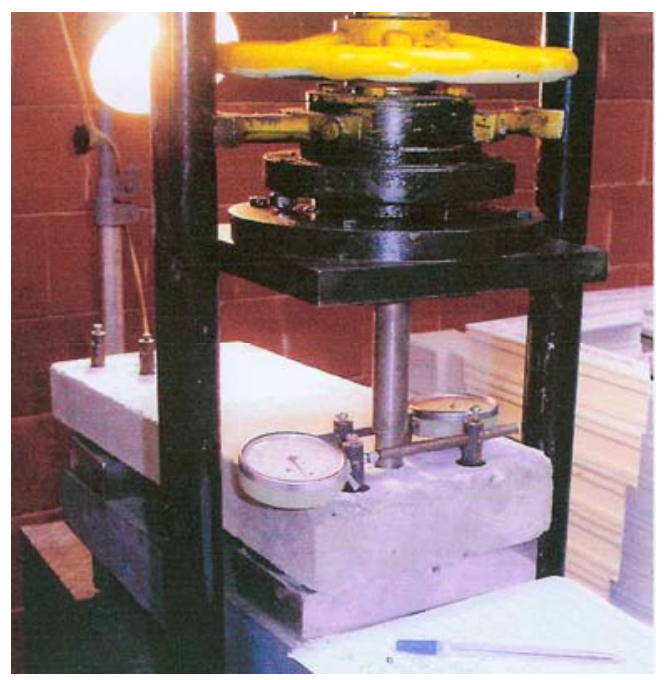

Fig 5. General view of the test set up

Parameters of the specimens and values of the pressure to the concrete $p_{c r}$ and $p_{u}\left(p_{c r}-\right.$ the pressure at which the concrete covers the reinforcement cracked, $p_{u}$ - pressure spalling off the concrete cover of reinforcement) are presented in Table 2 .

The investigation results indicate (Table 2) that for the specimens of series BII the ratio $p_{c r} / p_{u} \approx 1$. In these specimens the longitudinal crack propagated instantly in the stage of spalling off the concrete cover to reinforcement, ie cracking the cover and its spalling off took place at the same time (Fig 6). In the specimens of other series the longitudinal crack opened in the cover to reinforcement first (with exception of the cases with the specimens BIII-5 and BIII-6 in which the crack propagated at the same time on both sides), then gradually until the cover has spalled off. In this case ratio $p_{c r} / p_{u}$ is less that unity. When the longitudinal crack of normal fracture propagated behind the concrete cover, its propagation was influenced by transverse shear (Table 2).

The character of the longitudinal crack and its rate of propagation were influenced by the spacing of opened normal cracks and intensity of transverse horizontal reinforcement in a member. When the distance of the normal crack $c_{k}$ to the horizontal bar of the transverse reinforcement is larger, the ratio $\delta / c_{i}$ and the intensity of the transverse reinforcement $A_{s w} / s_{w}$ are smaller then the ratio $p_{c r} / p_{u}$ is closer to unity. The great influence of the normal cracks on propagating longitudinal cracks has been proved by investigations [9] as well. Relationship between pressures $p_{c r}$ and $p_{u}$ (Fig 7) may be expressed:

$$
p_{c r}=\chi p_{u},
$$

where $\chi=1,134-0,873 \sqrt{5 A_{s w} \delta /\left(s_{w} c_{k} c_{i}\right)} \leq 1$.

According to expression (3), the ratio of pressures $p_{c r} / p_{u}=1$, when there is no transverse reinforcement at all. Time dependent investigations indicate (section 2) that the concrete cover cracks before the final spalling off, ie during the action of sustained pressure of the rust due to the concrete creep the ratio $p_{c r} / p_{u}$ is less than a unit. Short time investigations of concrete specimens of series B showed that in a specimen without a transverse reinforcement propagation of longitudinal cracks is similar to the cracking of the specimens subjected to a longtime pressure developed by rust (Fig 3). After cracking of concrete cover, the position of vertical transverse reinforcement in cross-section of the member affects the propagation orientation of longitudinal cracks. Thus the proposed method of accelerated investigations [8] may be successfully applied to the analysis of propagation of such cracks.
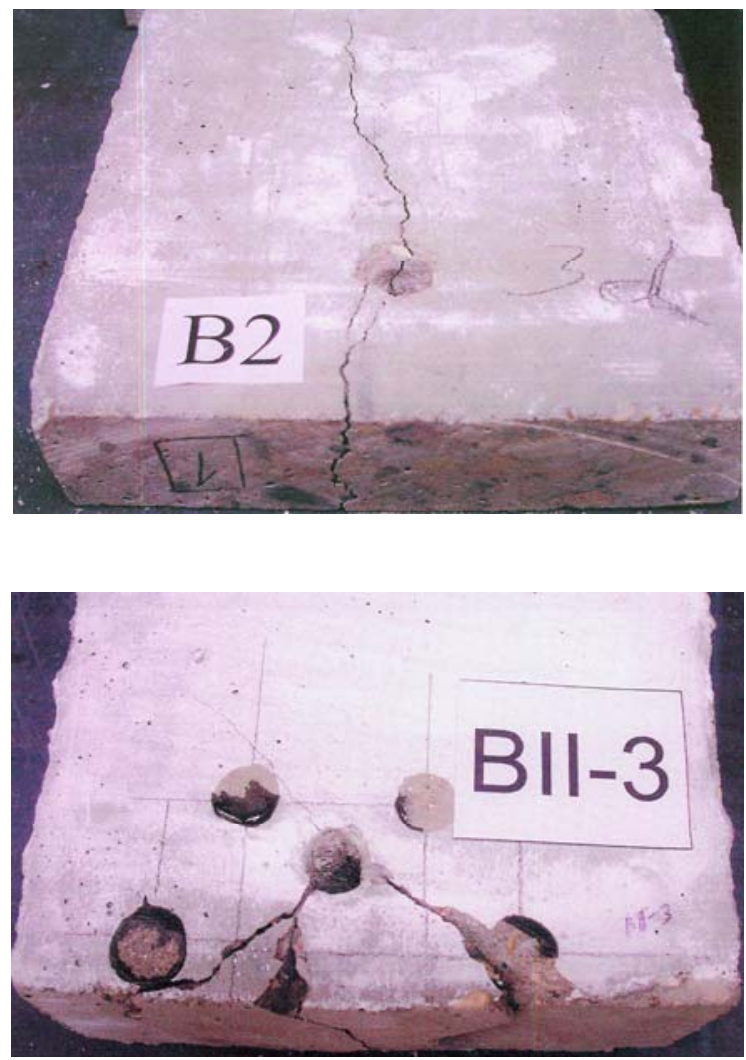

Fig 6. Propagation of a longitudinal crack in the specimens BII-3 and B2 in which the distance of $\delta$ was equal respectively to $21,8 \mathrm{~mm}$ and $40 \mathrm{~mm}$

Rank2 Eqn $12 \mathrm{y}=\mathrm{a}+\mathrm{bx}{ }^{0.5}$

$r^{2}=0,932326678$ DF Adj $r^{2}=0,927659552$ FitStdE $r r=0,0637556253$ Fstat $=413,306152$ $a=1,1342435$

$\mathrm{b}=-0,87261515$

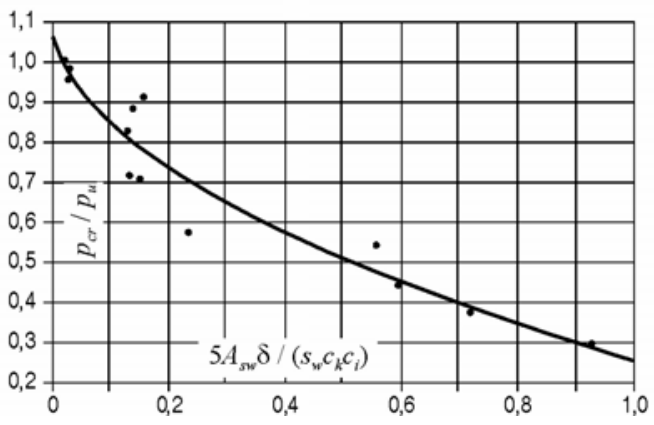

Fig 7. Variation of the ratio $p_{c r} / p_{u}$ 
Table 2. Parameters of the specimens and investigation results

\begin{tabular}{|c|c|c|c|c|c|c|c|c|c|c|}
\hline \multirow{2}{*}{$\begin{array}{l}\text { Specimen } \\
\text { mark }\end{array}$} & \multicolumn{7}{|c|}{ Parameters, mm } & \multicolumn{2}{|c|}{ Pressure, $\mathrm{MPa}$} & \multirow{2}{*}{$\begin{array}{l}\text { Character of } \\
\text { cracking }\end{array}$} \\
\hline & $t$ & $d$ & $\delta$ & $c_{i}$ & $c_{j}$ & $c_{k}$ & $s_{w}$ & $p_{c r}$ & $p_{u}$ & \\
\hline BI-1 & 49 & 22,6 & 22,7 & 20 & & 6 & 37 & 2,21 & 3,00 & \\
\hline BI-2 & 50 & 22,7 & 33,7 & 20 & 15 & 6 & 38 & 1,20 & 3,95 & \\
\hline BI-3 & 51 & 22,7 & 53,7 & 40 & 15 & 6 & 39 & 1,65 & 4,36 & \\
\hline BI-4 & 52 & 16,4 & 22,8 & 20 & $10-11$ & 6 & 40 & 1,87 & 4,18 & \\
\hline BI-5 & 51 & 16,6 & 41,7 & 40 & $10-11$ & 6 & 39 & 2,56 & 4,68 & \\
\hline BII-1 & 76 & 16,5 & 23,8 & 20 & 80 & 34 & 84 & 2,04 & 2,04 & \\
\hline BII-2 & 74 & 16,3 & 42,9 & 40 & 78 & 33 & 82 & 2,84 & 2,84 & \\
\hline BII-3 & 67 & 16,5 & 21,8 & 20 & $10-11$ & 29,5 & 75 & 2,27 & 2,30 & \\
\hline BII-4 & 69 & 16,4 & 43,8 & 40 & $10-11$ & 30,5 & 77 & 3,70 & 3,70 & \\
\hline BII-5 & 70 & 16,4 & 24,8 & 20 & $10-11$ & 31 & 78 & 1,68 & 1,75 & \\
\hline BII-6 & 71 & 16,5 & 42,8 & 40 & $10-11$ & 31,5 & 79 & 2,81 & 2,81 & \\
\hline BIII-1 & 102 & 16,3 & 23,9 & 20 & 80 & 16 & 70 & 1,73 & 2,08 & \\
\hline BIII-2 & 103 & 16,5 & 51,8 & 40 & 80 & 16 & 71 & 3,21 & 3,62 & \\
\hline
\end{tabular}


Continuation of Table 2

\begin{tabular}{|c|c|c|c|c|c|c|c|c|c|c|}
\hline \multirow{2}{*}{$\begin{array}{l}\text { Specimen } \\
\text { mark }\end{array}$} & \multicolumn{7}{|c|}{ Parameters, mm } & \multicolumn{2}{|c|}{ Pressure, MPa } & \multirow{2}{*}{$\begin{array}{c}\text { Character of } \\
\text { cracking }\end{array}$} \\
\hline & $t$ & $d$ & $\delta$ & $c_{i}$ & $c_{j}$ & $c_{k}$ & $s_{w}$ & $p_{c r}$ & $p_{u}$ & \\
\hline BIII-3 & 100 & 16,4 & 23,8 & 20 & $10-11$ & 16 & 68 & 1,11 & 1,54 & \\
\hline BIII-4 & 99 & 16,5 & 54,8 & 40 & $10-11$ & 16 & 67 & 3,43 & 3,74 & \\
\hline BIII-5 & 98 & 16,4 & 39,8 & 20 & $10-11$ & 16 & 66 & 1,75 & 3,00 & \\
\hline BIII-6 & 101 & 16,6 & 54,7 & 40 & $10-11$ & 16 & 69 & 2,70 & 3,79 & \\
\hline
\end{tabular}

Notes: $\quad 1$. In determining the pressure to $t$ concrete, friction between steel balls is neglected.

2. Broken lines indicate propagation of cracks in the stage of spalling off the concrete cover to reinforcement.

\section{Conclusions}

Results of investigations into corrosion of cast in concrete steel bars and concrete cracking indicate that propagation of longitudinal cracks has opened due to pressure developed by the rest and can be described by Eqs (1) and (2) used when evaluating the damage to reinforcement induced by corrosion [5]. Longitudinal crack of normal fracture cuts the concrete cover of the reinforcement first. After cracking of this layer a further crack propagation may be influenced by transverse shear. If in the crack developed earlier the layer of concrete cover are several branches (Fig 1), then the ratio $\lambda_{2}$ can be determined by the main branch according to which spalling off the concrete cover of reinforcement takes place.

Short time investigations in propagation of longitudinal cracks with a simulation of rust pressure according to [8] give an opportunity to assess with a sufficient accuracy the character of propagation of these cracks in reinforced concrete structures and to analyse an influence of transverse reinforcement, normal cracks, geometry of cross-section etc on this propagation.

Intensity of transverse reinforcement, distribution of this reinforcement in relation to normal cracks along the member influence the character and the rate of propagation of longitudinal cracks. A larger interval in the member (distance $c_{k}$ ) formed between longitudinal bars of transverse reinforcement and smaller ratios $A_{s} / s_{w}$ and $\delta / c_{i}$ result in a smaller difference between two corresponding pressures developed by rust, causing cracks in the concrete reinforcement cover and spalling off this cover. After cracking the orientation of propagation and the character of branching of longitudinal crack depends on distribution of vertical transverse reinforcement in the cross-section of the member.

\section{References}

1. DU, Y.G.; CHAN, A. H. C. A.; WILLIAMSON, S.; CLARK, L. A. FEM Analysis of Concrete Cracking due to Steel Corrosion. In Proc of the EURO-C 1998 Conference on Computational Modelling of Concrete Structures, Badgastein, Austria, March 31 - Apr 3, 1998. Ed. R. de Borst, N. Bicanic, H. A. Mang, G. Meschke. Rotterdam: Balkema, 1998, p. 481-490.

2. VU, K.; STEWART, M. G.; MULLARD, J. CorrosionInduced Cracking: Experimental Data and Predictive Models. ACI Structural Journal, 2005, 102(5), p. 719-726.

3. EL MAADDAWY, T.; SOUDKI, K.; TOPPER, T. LongTerm Performance of Corrosion-Damaged Reinforced Concrete Beams. ACI Structural Journal, 2005, 102(5), p. 649-656.

4. LI, Ch. Q.; MELCHERS, R. E. Time-Dependent Reliability Analysis of Corrosion-Induced Concrete Cracking. ACI Structural Journal, 2005, 102(4), p. 543-549.

5. JOKŪBAITIS, V.; KAMAITIS, Z. Cracking and Repair of Reinforced Concrete Structures. Vilnius: Technika, 2000. 155 p. (in Lithuanian).

6. JOKŪBAITIS, V.; JURKŠA, A. Modelling Formation and Development of Longitudinal Cracks in Concrete Crossing Corroding Reinforcement. Journal of Civil Engineering and Management, 2002, 8(3), p. 159-163.

7. Construction Technical Regulation. STR 2.05.05:2005. Design of Concrete and Reinforced Concrete Structures. Vilnius, Ministry of Environment, 2005. 123 p. (in Lithuanian).

8. JOKÜBAITIS, V. The Theoretical Simulation of the Corrosive Crack Openings in Reinforced Concrete. In Proc of $4^{\text {th }}$ International Conference "Modern Building Materials, Structures and Techniques", Vilnius, Lithuania, 10-13 May. Vilnius: Technika, 1995, p. 163-167 (in Lithuanian).

9. MIGUNOV, V. N. Experimental-theoretical Investigations on Influence of Corrosion-induced Damages to Reinforcing Steel of A-I and A-III Classes on Occurrence of Longitudinal Cracks and Modification of Durability of Reinforced Concrete Structures. Строительство (Building), 2004, No 1, p. 110-114 (in Russian). 


\section{ARMATŪROS KOROZIJOS ATSIV RUSIU BETONO PLYŠIU PLITIMO D SNINGUMAI}

\section{Jokubaitis}

Santrauka

Armatūros korozijos atsiv rusių betono išilginiu plyšiu plitimui analizuoti atlikti ilgalaikiai ir trumpalaikiai (paspartinti, imituojant susl gtụju rūdžių sl gi) eksperimentiniai tyrimai. Ilgalaikiuose bandymuose buvo tiriama išilginio plyšio pločio betono paviršiuje ir prie armatūros tarpusavio priklausomyb ir šių pločiu bei armatūros korozinių pažaidu ryšys; nustatyti šiu priklausomybių parametrai. Trumpalaikiais tyrimais buvo siekiama nustatyti, kokią îtaką išilginiu plyšių plitimo pobūdžiui turi gelžbetoninio elemento skersin armatūra ir atsiv rę normaliniai plyšiai. Nustatyta, kad nuo skersin s armatūros ir normalinių plyšiu tarpusavio išsid stymo išilgai elemento priklauso išilginių plyšių plitimo braižas ir greitis.

Reikšminiai žodžiai: korozija, rūdžių sluoksnis, plyšiai, skersin armatūra.

Vidmantas JOKŪBAITIS. Doctor, Assoc Prof, Dept of Reinforced Concrete and Masonry Structures, Vilnius Gediminas Technical University (VGTU), Saul tekio al. 11, LT-10223 Vilnius, Lithuania.

$\mathrm{PhD}$ (1960, civil engineering) at Kaunas University of Technology. Assoc Prof (1967). Research interests: evaluation of reinforced concrete structures with cracks in existing buildings. 